\title{
HISTORY, HISTORICAL MEMORY, MEMORY POLICY: THEORETICAL AND METHODOLOGICAL ASPECT
}

\author{
Yarosh Y. B., Kalishchuk O. M.
}

\section{INTRODUCTION}

One of the trends of modern science is the interdisciplinarity of research, which is particularly pronounced in the Humanities. This is a way to adapt the experience of the past to the realities and challenges of today. Thus, these searches represent the existence of memory in societies and the formation of boundaries of concepts related to it.

Over the past decades, Memory Studies have taken one of the leading positions not only in western Humanities, but also in the research of scientists from post-communist countries (including Ukrainian). It is interesting that the "memorial boom", which began in the 60s of the $20^{\text {th }}$ century, began to claim the status of a new paradigm of humanitarianism at the turn of the $1980 \mathrm{~s}-1990 \mathrm{~s}$, remains relevant to this day, covering more and more variety of historical topics and more and more scientists. We are talking about both theoretical developments and so-called CaseStudies (works on specific problems). As indicated by E. Langerbacher "memory cannot fail to be put forward in advance in any country that has suffered from a dictatorial regime or social trauma, and that has subsequently managed to restore peace and a democratic system".

It should be noted at once that some scientists perceive history and memory as synonymous, while others on the contrary - as antagonistic. Already the author of the first systematic substantiation of the concept and analysis of the phenomenon of collective memory, M. Halbwax contrasted history and memory: memory - unreliable, effective only

${ }^{1}$ Langenbacher E. Collective Memory as a Factor in Political Culture and International Relations. Power and the Past Collective Memory and International Relations. Ed. by E. Langenbacher, Y. Shain. Washington: Georg Town University Press, 2010. P. 13-49. 
during repetitions, modernizes the mentioned, and history is documented, deals with unique events and critically distances itself from the present. Modern researchers also contrast these concepts. Therefore, Yaroslav Gritsak, answering the question "What is historical memory" without any reservations confirmed "This is something that is not history. It is a distorted and bad mirror of what was actually" and clearly the difference between these phenomena. The study of history is aimed at the most accurate reflection of the past, often based on theories and approaches borrowed from other disciplines. On the contrary, the oral tradition of transmitting information about the past is mythological and is characterized by the fact that memory preserves and "reproduces" the past based on imagination generated by feelings and sensations caused by the present. After all, memories of past events are reproduced through the prism of modernity.

\section{Historical memory}

If history (or more precisely, historical science) has a certain ontological and epistemological status as a science, then this cannot be said about "historical memory". It is no accident that N. Yakovenko suggests the concept of "historical memory" in quotation marks, since it does not exist in history as a science. We should agree with those researchers who claim that all research in the field of historical memory is focused around several common tasks: the most common is to define the concept itself. Some researchers point to the ambiguity of the use of the concept and term "historical memory", despite its active use in social and political vocabulary and professional literature. The discrepancies indicate that a clear definition has not yet been developed, and therefore the boundaries of the concept are not defined and the term is used in different senses. Generalization of various approaches to the nature of the relationship between history and memory allows us to distinguish the following positions: history and memory are opposed, even considered as incompatible phenomena; history and memory are identified; history and memory are interpreted as a form of understanding, interpretation and 
representation of the past and are in the process of constant interaction, mutual complementarity ${ }^{2}$.

In the context of the outlined problem, it should immediately be emphasized that researchers do not have a single definition of the essence of the concept of "historical memory". German scholar Th. Ruzen believed that historical memory, on the one hand, is the mental ability of the subject to retain memories of past experiences, which is the basis for the formation of historical consciousness, and on the other - it is the result of certain sensorimotor operations to produce memories formed in the process of forming historical consciousness due to the understanding of historical experience ${ }^{3}$. In this sense, as $\mathrm{N}$. Yakovenko notes, "historical memory" is likened to myth, because it chooses from the chaotic flow of existence only certain values that are necessary for the community, and also allows you to overcome the transience and fleetness of the life of an individual"4.

We also recall the definition of $\mathrm{P}$. Tronko, according to which historical memory is "a kind of focused consciousness that reflects the significance and relevance of information about the past in close relationship with the present and future"5. It is an expression of the process of organizing, preserving and restoring the experience of the people for possible use in the activities of people or for returning its influence to the sphere of public consciousness. Russian researcher $\mathrm{Zh}$. Toshchenko pointed to the ability to hold in the minds of people the main historical events of the past up to the transformation of historical knowledge into various forms of worldview perception of the experience as a feature of historical memory ${ }^{6}$. In a more imaginative definition of historical memory, V. Masnenko claims about it as a kind of

${ }^{2}$ Касьянов Г. Історична пам'ять та історична політика: до питання про термінологію й генеалогію понять. Украӥнський історичний журнал. 2016. № 2. С. 118-137.

${ }^{3}$ Rüsen J. Historische Orientierung. Über die Arbeit des Geschichtstewusstseins sich in der Zeit yurechzrubinden. Cologne, Weimar, and Vienna: Böhlau, 1994.

${ }^{4}$ Яковенко Н. Вступ до історії. Київ: Критика, 2007. С. 34.

5 Тронько П. Інститут національної пам'яті як засіб зцілення від пострадянської ментальності. Дзеркало тижня. 2005. 19-25 листопада (№ 45).

${ }^{6}$ Тощенко Ж. Историческое сознание и историческая память. Анализ современного состояния. URL: http://vivovoco.rsl.ru/VV/JOURNAL/newhist/himem.htm 
psychological equipment of a community or individual as a "matrixsieve", through the holes of which only what causes emotional stress or outrage of public passions is sifted ${ }^{7}$. One way or another, historical memory can be interpreted as the ability of public actors to preserve and transmit from generation to generation knowledge about historical events, historical figures, national heroes and apostates, about traditions and collective experiences of mastering the social and natural world, about the stages of development that a particular ethnic group, people, or nation has passed through ${ }^{8}$.

At the same time, a number of authors expand the discourse of memory. According to Ya. Assman: "Everyone says that a new paradigm of cultural Sciences is being built around the concept of memories; that various phenomena and spheres of culture - art and literature, politics and society, religion and law-can be considered in new relationships" ${ }^{\text {. In }}$ the interpretation of A. Vasyliev historical memory is "a transdisciplinary field of historical and cultural character that has its own subject, that is, one that allows us to consider the entire set of phenomena of human culture from a certain angle, seeing their relationship from the position of how "images-memories" were stored, transmitted, updated, displaced and used in a particular culture" 10 .

It is worth agreeing with A. Kyrydon that the peculiarity of the formation of domestic historiographical discourse is that the first (often unconscious) use of the term "historical memory" had mainly a metaphorical meaning. In the mass media and journalism, the concept of "historical memory" was accepted at the level of metaphor or phraseological turnover, but it was thanks to the media, cinema,

${ }^{7}$ Тощенко Ж. Историческое сознание и историческая память. Анализ современного состояния. URL: http://vivovoco.rsl.ru/VV/JOURNAL/newhist/himem.htm

${ }^{8}$ Ярулин И. Ф. Историческая память как социальный гипноз: к методологии исследования. Вестник Тихоокеанского государственного университета. 2016. № 3 (42). C. 148 .

${ }^{9}$ Ассман Я.Культурная память: Письмо, память о прошлом и политическая идентичность в высоких культурах древности. Пер. с нем. М. М. Сокольской. М., 2004.

${ }^{10}$ Васильев А. Memorystudies: единство парадигмы - многообразие объектов. Новое литературное обозрение (НЛО). 2012. № 5. С. 461-480. 
documentaries, literature, etc. that the concept was actualized in the mass consciousness ${ }^{11}$.

During a kind of trend for memory and at the same time a superficial delving into social and historical processes, it becomes possible to use historical memory, that is, “... the generalized collective experience of a social group or society as a whole, which is formed in the process of developing a person's thinking about the world, is relevant for the current generation" 12 to achieve modern political goals. Not by chance, H. Kasianov generally interprets historical memory as "a relatively stable set of interconnected collective ideas about the past of a certain group, purposefully constructed by means of historical policy, codified and standardized in social, cultural, political discourses, myths, symbols, mnemonic and comemoral practices. Historical memory, on the one hand, is the result of cultural, social, and political construction, but also, in turn, becomes a means of constructing cultural, social, political, and religious identity, which in the era of nationalism are synthesized into a national identity"13. This statement is supplemented by the conclusion of Ch. Valtser "Memory is not so much connected with the past as with the present" $"$.

It should be recognized that the concept of "historical memory" appeared in historiography on the one hand, it stimulated the structuring of multi-level formation of ideas about the past, on the other hand, it complicated the conceptual disorder.

In Western Europe, they tried to create a new culture of memory "apology and repentance" for the crimes of totalitarian (authoritarian) regimes. The Holocaust became the strategic dividing line in the politics of memory. Now in modern historiography, there are several models and

${ }^{11}$ Киридон А. Студії пам'яті в Україні: основні тенденції становлення. Україна Eвpona-cвim. 2014. № 14. С. 265-274.

12 Тавокин Е. П., Табатадзе И. А. К вопросу об исторической памяти о Великой Отечественной войне. Социс. 2010. № 5. С. 62.

13 Касьянов Г. Історична пам'ять та історична політика: до питання про термінологію й генеалогію понять. Украӥнський історичний журнал. 2016. № 2. С. 135.

${ }^{14}$ Вельцер Х. История, память и современность прошлого. Память как арена политической борьбы. Неприкосновенный запас. 2005. № 2-3. С. 10. 
strategies for overcoming the "inconvenient" past (first of all, the events of the Second World War). Lviv scientist Yaroslav Hrytsak identified Spanish, German, Anglo-Saxon Western European and Russian models of memory ${ }^{15}$. At the same time, the famous intellectual in his research drew attention to the peculiarity of historical memory in Ukraine and its inability, in his opinion, to be unified and common for all Ukrainians, which caused a long period of stay of Ukrainian lands as part of their native state entities ${ }^{16}$. Another domestic researcher Vladyslav Hrynevych in the national memory policy of the countries of Central and Eastern Europe identified the Eastern European/Baltic, Western European (German liberal-democratic), and post-Soviet (Russian-Belarusian) models of memory of the Second World War ${ }^{17}$. The Polish historian and political scientist Tomasz Stryiek turned to the Polish and Baltic models (not bypassing the Spanish) ${ }^{18}$. Yurii Shapoval drew attention to the reconciliation policy in Spain and the application of its positive elements in the Ukrainian context ${ }^{19}$. Olha Hnatiuk ${ }^{20}$, Andrii Portnov ${ }^{21}$,

${ }^{15}$ Грицак Я. 26-й процент, або як подолати історію. Київ: Фонд Порошенка, 2014.

${ }^{16}$ Грицак Я. Нариси історії України: формування української модерної нації XIXXX століття. Київ: Видавництво «Генеза», 2000; Грицак Я. Парадокси національної ідентичності. URL: https://day.kyiv.ua/uk/article/podrobici/paradoksi-nacionalnoyi-identichnosti

${ }^{17}$ Гриневич В. Український вимір війни та пам'яті про неї. Сучасні дискусї̈ про Другу світову війну: збірник наукових статей та виступів українських і зарубіжних дослідників. Львів: ЗУКЦ, 2012. С. 50-64.

${ }^{18}$ Стриєк Т. «Війна за війну» 2005-2010 pр. Стратегії політики пам’яті про події 1930-х - 1950-х років у Центральній та Східній Європі. Сучасні дискусії про Другу світову війну: збірник наукових статей та виступів українських і зарубіжних дослідників. Львів: ЗУКЦ, 2012. С. 34-49; Стриєк Т. Україна в дзеркалі Іспанії. Політика пам'яті на зламі XXXXI ст. і націотворчі процеси на двох кінцях Європи. Невловимі категорії. Нариси про гуманітаристику, історію і політику в сучасних Україні, Польщі та Росії. Київ: НікаЦентр, 2015. C. 207-240; Stryjek T. Ukraina w zwierciadle Hiszpanii: polityka wobec pamięci na przełomie XX i XXI w. a procesy narodowotwórcze na dwóch końcach Europy. Alvydanas Nikžentaitis i Michał Kopczyński, red., Dialog kultur pamięci $w$ regionie ULB. Warszawa: Muzeum Historii Polski, 2014. S. 215-246; Stryjek T. “Jak powtórzyć osiemnastego brumaire'a: o dramacie w historii i farcie w polityce wobec pamięci w Chorwacji, Serbii i na Ukrainie od 1991 r. Jak patrzeć na Polskę, Niemcy i świat?: księga jubileuszowa profesora Eugeniusza Cezarego Króla Joanna Szymoniczek, red. Warszawa: Bellona: Instytut Studiów Politycznych Polskiej Akademii Nauk, 2017. S. 594-630.

${ }^{19}$ Шаповал Ю. Політика національного примирення в Іспанії: що корисне для України. Національна та історична пам'ять: зб. наук. пр. Вип. 5. Київ: ДП НВЦ «Пріоритети», 2012. С. 190-195; Шаповал Ю. Примирення по-іспанськи. Коспроміс після громадянської війни. День. 2013. 18 лютого. 
Michal Urban ${ }^{22}$ and others wrote separately about the Polish experience of forming and preserving historical memory.

German model. The German example of overcoming a difficult past should be considered the most textbook in Europe. A well-known German culturologist Aleida Assman have identified the remaining four stages of transformation of historical memory that survived Germany. The first was a period that could be described as "general oblivion". The second period is "remember so that you never forget" (this is a mandatory stage of memory transformation, since the future must be built on the meeting with the past). The third period is "remember to overcome", which reveals the transformational potential of memory when forgetting goes through remembering and forgiving. Finally, the fourth is when the so-called "dialogic memory" is built, when there is an internal reconstruction of communities that have a common history, and the goal of the process is to discuss the past and settle accounts with it ${ }^{23}$.

The period of the $40 \mathrm{~s}$ - to the mid-60s $20^{\text {th }}$ century in both cases, Germany was designated the "silent phase", when the Germans sought to forget about the Nazi past, believing that the status of the defeated in the war gave them such an opportunity. Representatives of the former Nazi regime and the "grey majority", which during the Third Reich passively supported Hitler (the so-called "fellow travellers"), agreed in a common desire to "forget" the recent past, as well as to get rid of the guilt that burdened the Fuhrer and his inner circle. The few voices trembling from Nazism, historians and writers who called to repent and draw conclusions

20 Гнатюк О. Обличчя історичної пам'яті. Доробок польського Інституту національної пам'яті та суспільні дискусії. Культура історичної пам'яті: європейський та український досвід. Ю. Шаповал, ред. К: НАНУ, 2013. С. 280-300.

21 Гнатюк О. Обличчя історичної пам'яті. Доробок польського Інституту національної пам'яті та суспільні дискусії. Культура історичної пам'яті: європейський та украӥнський досвід. Ю. Шаповал, ред. К: НАНУ, 2013. С. 280-300.

22 Гнатюк О. Обличчя історичної пам'яті. Доробок польського Інституту національної пам'яті та суспільні дискусії. Культура історичної пам'яті: європейський та украӥнський досвід. Ю. Шаповал, ред. К: НАНУ, 2013. С. 280-300.

${ }_{23}$ Ассман А. Длинная тень прошлого: мемориальная культура и историческая политика. Пер. с нем. Б. Хлебникова. М.: Новое обозрение, 2014. 
did not find understanding. This process was also influenced by the "cold war", which made Germany an element and ally of the Western world and opposed it, respectively, to the USSR.

The next phase was the "phase of understanding conclusions from the past", which can be chronologically designated from the mid-1960s to the early 1990s. The change of generations allowed us to break the "cursed questions" that were hushed up by parents. Gradually (thanks to the efforts of young people and historians who were not afraid to talk about the horrors of Reich's time) the Germans began to partially realize their collective guilt, mainly for the Holocaust. "This was a positive shift, which, however, laid the foundation for the future hierarchy of victims of Nazism, when against the background of the "victim of the first turn" Jews who forget and do not notice others who suffered from Hitler's terror" ${ }^{24}$. This phase was logically completed by the stormy discussions of 1986-1987 with the participation of not only historians, but also the political leadership of Germany.

Third, we will define the phase of "active memory culture". During the 1990s and early 2000s, the country held open Museum and memorial events with the involvement of photographic documents and testimonies of participants in the events of the war. The most painful and shocking thing for the public was to realize that Hitler was supported by the vast majority of the German population, and that $99 \%$ of them were somehow (directly or indirectly) involved in the crimes of that time. Obviously, the disclosure of the truth about the times of the Third Reich caused resistance from a part of society (regardless of age).

Spanish model. The Spanish experience is based on the acceptance by the citizens of the country of an informal pact on amnesia that is, forgetting all the political excesses of the past in order to avoid them in the future. The policy of "reconciliation" or "oblivion" introduced during the transition from dictatorship to democracy was in effect until the mid-1990s. Due to the unwritten agreement between the

24 Леньо П. Ю. Забуття чи подолання минулого? Німецький досвід вирішення проблем колективної вини та відповідальності. Науковий вісник Ужгородського університету, серія «Історія». 2014. Вип. 33. С. 162. 
main social and political groups of post-Franco Spain, he categorically rejected any attempts to use historical disputes outside the scientific and historiographical plane, thus giving history to historians. This position allowed us to reject historical revanchism on the part of the vanquished for the sake of the "common good" in the future and for the time being restrained discontent with historical memory, which broke through to the surface when the "fears of the past" were forgotten.

Initiated at that time "the war for history" acquired categorical forms, first of all because of the intervention of political parties that sought to "privatize" the past by manipulating their own historical images ("left" - loser democrats that were defeated in the war against "fascism" and forced to agree to "reconciliation" for the sake of democratic system restoration; "right" - Spanish patriots" who, against all odds, tried to keep "unity" of the Spanish nation, which, in particular, undermines the "disinterested" in history devoid of the feeling of unitarity and continuity of Spanish history) ${ }^{25}$.

It should be considered that Spain has passed four stages in creating a national memory: 1) the denial of memory (1936-1977); 2) the policy of oblivion (1977-1981); 3) the suspension of memory (1982-1996); 4) the revival of memory (since 1996). The fact is that not often remember the initiative of Franco April 1937 "Decree of unity", which to a certain extent united the monarchists and supporters of the Phalanx. Later, King Juan Carlos and the government led by Prime Minister Adolfo Suarez initiated the conclusion in October 1977 the Pact of national accord, which was called the "Moncloa Pact" (after the Palace-residence of the leadership of the Spanish government in Madrid) with all the parties responsible for the fate of the country.

In Ukraine, the famous intellectual and historian Yaroslav Hrytsak came up with ideas of "memory freezing" like the Spanish one. However, this position has not found support in society. According to Vladyslav Grynevych, the historical experience of these countries was too different.

25 Чума Б. «Іспанська «війна за історію»: політика, історіографія та шкільна освіта». Україна модерна. 2012. Ч. 19: Як (не) писати підручники з історії. С. 63-88. 
In Spain, there was a civil war and the conflict was polarized between the right and left citizens of the same state. Nevertheless, in post-Communist and post-colonial Ukraine, the conflict was between supporters of the "red Empire" and independence. Ukrainian society, after decades of silence, sought to reveal the truth about the crimes of totalitarian regimes (the Holodomor, mass repression, deportation of Crimean Tatars, the Holocaust, and so on), and the idea of a Pact of oblivion did not meet the public's needs $^{26}$.

Baltic model is based on parliamentarism as an expression of public opinion, including on historical topics. The President acts as a symbol of identity and "Keeper" of national memory. Defining for these countries is the formation of the memory of the titular nation while preserving the youthfulness of the development of an alternative memory model.

The leadership of the Baltic countries of Lithuania, Latvia and Estonia tries to influence historical discussions and attaches great importance to historical education. This is reflected in the creation of institutions of national memory in the Baltic States, whose task is to develop a strategy for the "correct" popularization of national history. The main strategic task remained the process of balancing the image of a victim, hero or participant in the crimes of World War II, and recognizing responsibility for crimes against Jews. Anti-Jewish pogroms at the beginning of the Nazi occupation explain the participation of Jews in the Soviet repressive apparatus, state security agencies that committed crimes against the Baltic Nations during 1940-1941. In historiography, this was called the "concept of two genocides" and brought a certain division and rivalry for the title of the most affected nation. Honouring the heroes of the struggle for independence in 1940-1941 and 1944-1953, who, in turn, were involved in the anti-Jewish pogroms of 1941-1944, remains a controversial issue.

${ }^{26}$ Гриневич В. Подолання тоталітарного минулого. Ч. 1: світовий досвід. URL: http://uamoderna.com/blogy/vladislav-grinevich/totalitarianism1 
As we can see, the number of studies of various aspects of historical memory, its formation and functioning is only growing. Among others, we should highlight the problems of social functions, mechanisms of functioning, the relationship between historical memory and national and regional identity.

\section{2. "Memory Policy"}

Memory structures are embedded in the political process and are constantly reproduced in various symbolic actions (public holidays, the installation and dismantling of monuments, places of memory). Therefore, the state builds a certain line of interpretation of historical events, which is based on the awareness of citizens of belonging to the nation, citizenship.

As in all other cases with multiple currents within Memory Studies, we are dealing with a variety of definitions: historical politics, memory politics, public history, and even applied history. This applies to both the domestic context and the situation in the English-speaking environment: memory politics, politics of remembrance, politics of history, past politics, public history, applied history, history marketing. The concept of "memory politics" arose in the second half of the $20^{\text {th }}$ century in the philosophical concepts of postmodernists (R. Barth, Y. Kristieva, J. Derrida, M. Foucault), who put forward the thesis about the construction by the government and society of ideas about the past, the most successful for the formation of social and group identity. The practical use of the term "memory policy" dates back to the early 1980s. In Germany, when German Chancellor Helmut Kohl began a policy of forming German patriotism of a positive character, that is, based not only on the recognition of the German people's own guilt for the crimes of Nazism, but also an understanding of their own German nation and its culture $^{27}$. After 2004 the concept of "Geschichspolitik" was revived in Poland as "polityka historyczna", giving it a new, positive meaning after

${ }^{27}$ Петелин Б. В. Гульмут Коль: отвечая на вызовы истории. Журнал региональной истории. 2017. Т. 1, № 2. С. 12. 
some intellectuals made a call in the mass media to develop and vigorously pursue a patriotic "historical policy".

According to the classification of A. Kyrydon, all the variety of interpretations of this concept can be divided into two approaches. The first-value-is defined as a variety of social practices and norms related to the regulation of collective memory ( $\mathrm{Zh}$. Mink), as a conscious strategy for designing images of the past in plans for the future (P. Nora), as a public space for dialogue between social forces and historians (A. Miller). The second-constructivist-as imposed memory and permitted history (P. Ricker), as "creating criteria for selecting those historical events that are worth storing in the memory of those that need to be "erased" from it, the program and from it "erased", the program and actions to implement these criteria in the mass consciousness in order to turn them into unconscious stereotypes, as the development and promotion of the context in which events selected for restoration in the mass consciousness are combined with actual reality and set politically appropriate attitudes and preferences (P. Kara-Murza), as a process of extraction of images of the past that are contrary to the moods of the epoch (and certain political forces), a symbolic resource that is quite acceptable to use, including in the process of political and cultural rivalry of elites (Yu. Shapoval) ${ }^{28}$.

The offensive of memory on history was acutely perceived by historians in their professional environment. O. Miller's definition clearly emphasizes this threat of "intrusion" into academic discourse: "historical politics is a qualitatively different, much more intense than usual, intervention in the interpretation of history of the part of the political elite that controls power at the moment" ${ }^{\prime 2}$. If we consider the policy of memory from the perspective of a historian, then this is a professional study, the result of which is the reproduction of ideas about the past, the institution of the state in this case is responsible only for the stage of

${ }^{28}$ Киридон А. М. Політика пам’яті в Україні (1991-2015 рр.). Україна - Свропа Cвim. C. 244-245.

${ }^{29}$ Миллер А. Россия: власть и история. ProetContra. 2009. № 3-4. С. 8. 
reproduction, in particular delegating to other social institutions, the interpretation remains for scientists. Thus, memory comes to the fore, its opposition to oblivion, and not "politics"30. Researcher D. Anikin believes that the term "memory policy" is more acceptable and successful in scientific discourse and defines memory policy as a purposeful activity to represent a certain image of the past, which is in demand in a political context, through a variety of verbal (speeches of politicians, history textbooks) and visual (monuments, state symbols) practices ${ }^{31}$.

Since any policy is carried out to achieve a goal, it is logical, that memory policy is used to promote self-identification and social cohesion. In the understanding of some researchers, historical policy is "the conscious and purposeful use of history as an instrument of political struggle", and memory policy, respectively, is actions aimed at the formation and reproduction of identities, primarily national identity ${ }^{32}$.

Ukrainian researcher A. Konyk considers memory policy as a study of the role of a political project, an order to form and consolidate values, knowledge about the past with a specific social and political goal. At the same time, the researcher points to the exercise of control by the power elite or the dominant elite over the construction of knowledge about the past as the essence and purpose of memory policy ${ }^{33}$.

Attention is drawn to the relation of concepts programmed by O. Malynova ${ }^{34}$.

30 Рубцова В. Ю. Политика памяти в практике конструирования локальной идентичности. Вестник Удмуртского университета. Социология, Политология, Международные отношения. 2017. Т. 1, вып. 4. С. 451.

31 Аникин Д. А. Стратегии практики памяти на постимперском пространстве. Известия Саратовского университета. Серия Философия. Психология. Педагогика. 2012. T. 12. Вып. 2. С. 34-41.

32 Ачкасов В.А. Роль «исторической политики» в формировании российской идентичности. Журнал социологии и социальной антропологии. 2015. № 2 (79). С. 181-192.

${ }^{33}$ Коник А. «Історична пам'ять» та «політика пам'яті» в епоху медіа культури. Вісник Львівського університету. Серія Журналістика. 2009. Вип. 32. С. 157-158.

34 Малинова О. Ю. Политика памяти как область символической политики. Методологические вопросы изучения политики памяти: сб. науч. тр. Под ред. А. И. Миллера и Д. В. Ефременко. М. - СПб: Нестор-История, 2018. С. 34; Малинова О. Ю. Коммеморация исторических событий как инструмент символической политики: возможности сравнительного анализа. Полития. 2017. № 4 (87). С. 10. 


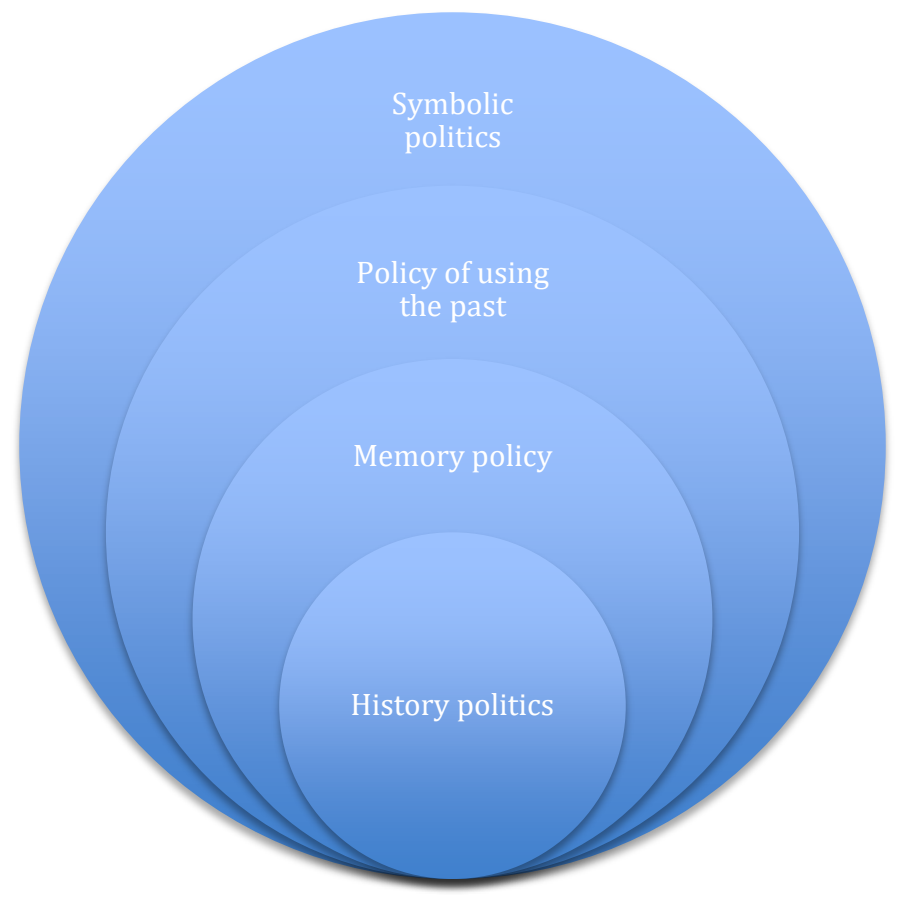

In this approach, historical policy is a single version of memory policy. In this case, it is characterized by the active participation of power institutions and the pursuit of party-ideological interests, which determines the confrontational nature. The essence of memory politics is an irreconcilable confrontation between political opponents, in which there must be a winner and a loser. For this interpretation of the politics of memory is no room for compromise and common interpretations.

\section{CONCLUSIONS}

The politicization and mediatization of history, the functioning and use of memory to achieve political goals, determine the research interest in this issue. One of the mandatory conditions for the success of scientific (and not only) discussion is the agreement of its participants of the terms that they will use to define certain concepts, phenomena, events. How 
interdisciplinary memory studios in modern Humanities actualize intersubject dialogue and perspectives of combining those concepts that were competing and mutually exclusive at previous stages. A review of methodological concepts developed by historians, political scientists, and sociologists, which are related to the memory of the past, is obviously not exhaustive. However, it emphasizes the possible approaches of scientists to understanding the past, the relationship of the past, present and future (especially through the prism of the influence of power on these processes).

Following other authors, we will confirm that the understanding and expansion of memory studios is intended to teach (both ordinary citizens and political figures) the value of their own and other people's memories, to search for areas of dialogue, coordination, and exchange of experience. We are also talking about the formation of a kind of valuemoral atmosphere in society, where different positions regarding the past and its distinctive images will form a constructive basis for interaction between political actors. By opening up opportunities for competing experiences and legitimizing controversial interpretations, the modern memorial paradigm can become a serious foundation for the development of a tolerant, democratic society devoid of destructive and violent forms.

\section{SUMMARY}

The concepts of "history", "historical memory", "historical policy" and "memory policy" are revealed and compared. It is shown that historical memory can: first, precede direct influence as a means of influence that is, determine the features of implementation; second, constitute the final goal of influence on the transformation of the object of influence. The main forms of manifestation of the phenomenon of remembrance and its features in societies are updated. The harmful influence of historical traumas on the historical consciousness and historical memory of societies is demonstrated. The processes that affect the state of scientific development of the problem are outlined. It is demonstrated that the combination of methods of historiographical research and modern theoretical and methodological approaches 
(in particular, the methodology of memory studios, the history of interactions, postcolonial and Imperial studios, etc.) will allow us to go beyond the classical historiography and solve research problems about the possibility/impossibility of mutual influence of historical science and memory policy.

\section{REFERENCES}

1. Langenbacher E. Collective Memory as a Factor in Political Culture and International Relations. Power and the Past Collective Memory and International Relations. Ed. by E. Langenbacher, Y. Shain. Washington: Georg Town University Press, 2010. P. 13-49.

2. Ponczek E. Polityka wobec pamięci versus polityka historyczna: aspekty semantyczny, aksjologiczny i merytoryczny w narracji polskiej. Przegląd Politologiczny. 2013. Nr 2.

3. Rüsen J. Historische Orientierung. Über die Arbeit des Geschichtstewusstseins sich in der Zeit yurechzrubinden. Cologne, Weimar, and Vienna: Böhlau, 1994.

4. Stryjek Tomasz, "Jak powtórzyć osiemnastego brumaire’a: o dramacie w historii i farcie w polityce wobec pamięci w Chorwacji, Serbii i na Ukrainie od 1991 r.," w Joanna Szymoniczek, red., Jak patrzé́ na Polskę, Niemcy i świat?: księga jubileuszowa profesora Eugeniusza Cezarego Króla (Warszawa: Bellona: Instytut Studiów Politycznych Polskiej Akademii Nauk, 2017), 594-630.

5. Stryjek Tomasz, "Ukraina w zwierciadle Hiszpanii: polityka wobec pamięci na przełomie XX i XXI w. a procesy narodowotwórcze na dwóch końcach Europy," w Alvydanas Nikžentaitis i Michał Kopczyński, red., Dialog kultur pamięci $w$ regionie ULB (Warszawa: Muzeum Historii Polski, 2014), 215-246;

6. Urban Michał, "Pamięć historyczna jako kulturowe podłoże relacji polsko-ukraińskich," Chorzowskie Studia Polityczne 12 (2016): 79-90;

7. Urban Michał, "Trauma jako czynnik nieporozumienia: kazus polsko-ukraińskich sporów o UPA," Miscellanea Posttotalitariana Wratislaviensia 6 (2017): 45-578 
8. Zawierszynskiej K. Pamięć polityczna i polityka pamięci w teorii i praktyce symbolicznej dominacji lit postradzieckich. Politeja. 2015. Nr 34/2. S. 101-116.

9. Аникин Д. А. Стратегии практики памяти на постимперском пространстве. Известия Саратовского университета. Серия Философия. Психология. Педагогика. 2012. Т. 12. Вып. 2. C. 34-41.

10. Ассман А. Длинная тень прошлого. Мемориальная культура и историческая политика. 2-е изд. / Пер. с нем. Б. Хлебников. 2018.

11. Ассман Я. Культурная память: Письмо, память о прошлом и политическая идентичность в высоких культурах древности. Пер. с нем. М. М. Сокольской. М., 2004.

12. Ачкасов В.А. Роль «исторической политики» в формировании российской идентичности. Журнал социологии и социальной антропологии. 2015. № 2 (79). С. 181-192.

13. Вельцер Х. История, память и современность прошлого. Память как арена политической борьбы. Неприкосновенный запас. 2005. № 2-3. С. 10.

14. Гнатюк О. «Обличчя історичної пам'яті. Доробок польського Інституту національної пам'яті та суспільні дискусії» в Ю. Шаповал, ред., Культура історичної пам'яті: європейський та український досвід. К: НАНУ, 2013, 280-300.

15. Гриневич В. «Подолання тоталітарного минулого. Ч. 1: світовий досвід»

16. Гриневич В. Український вимір війни та пам'яті про неї. Сучасні дискусї про Другу світову війну: збірник наукових статей та виступів українських і зарубіжних дослідників. Львів: ЗУКЦ, 2012. C. 50-64.

17. Грицак Я. 26-й процент, або як подолати історію. Київ: Фонд Порошенка, 2014.

18. Грицак Я. Нариси історії України: формування української модерної нації XIX-XX століття. Київ: Видавництво «Генеза», 2000. 
19. Зерній Ю. О. Як суспільства пам’ятають: властивості та механізми функціонування історичної пам'яті. Стратегічні пріоритети. 2008. № 4 (9). С. 35-43.

20. Касьянов Г. Історична пам'ять та історична політика: до питання про термінологію й генеалогію понять. Украӥнський історичний журнал. 2016. № 2.

21. Киридон А. М. «Історична пам'ять» у просторі політики пам'яті. Історичні і політологічні дослідження. 2018. Спецвипуск: доповіді на міжнародній науково-практичній конференції «Трансформації історичної пам'яті». С. 45-53.

22. Киридон А. М. Політика пам'яті в Україні (19912015 рр.). Україна - Свропа - Світ. Серія: Історія, міжнародні відносини. 2015. Вип. 15. С. 244-250.

23. Киридон А. М. Студії пам'яті в сучасній гуманітаристиці: історія становлення. Украӥнський історичний журнал. 2017. № 4. C. $150-161$.

24. Коник А. «Історична пам'ять» та «політика пам'яті» в епоху медіакультури. Вісник Львівського університету. Серія журналістика. 2009. Вип. 32. С. 153-163.

25. Леньо П. Ю. «Забуття чи подолання минулого? Німецький досвід вирішення проблем колективної вини та відповідальності». Науковий вісник Ужгородського університету, серія «Історія». 33 (2014):162.

26. Малинова О. Ю.Коммеморация исторических событий как инструмент символической политики: возможности сравнительного анализа. Полития. 2017. № 4 (87).

27. Малинова О. Ю. Политика памяти как область символической политики. Методологические вопросы изучения политики памяти: сб. науч. тр. Под ред. А. И. Миллера и Д. В.. Ефременко. М. - СПб: Нестор-История, 2018.

28. Масненко В. Історична пам'ять як основа формування національної свідомості. Український історичний журнал. 2002. № 5. C. 49-62. 
29. Миллер А. Россия: власть и история. ProetContra. 2009. № 3-4.

30. Петелин Б. В. Гульмут Коль: отвечая на вызовы истории. Журнал региональной истории. 2017. Т. 1, № 2.

31. Портнов А. Люстрація та інститути національної пам'яті у посткомуністичній Європі. URL

32. Рубцова В. Ю. Политика памяти в практике конструирования локальной идентичности. Вестник Удмуртского университета. Социология, Политология, Международные отношения. 2017. Т. 1, выП. 4. С. 450-455.

33. Стриєк Т. Україна в дзеркалі Іспанії. Політика пам’яті на зламі XX-XXI ст. і націотворчі процеси на двох кінцях Європи. Невловимі категоріі. Нариси про гуманітаристику, історію $i$ політику в сучасних Україні, Польщуі та Росї. Київ: Ніка-Центр, 2015. С. 207-240.

34. Стриєк Томаш, «Війна за війну» 2005-2010 рр. Стратегіï політики пам'яті про події 1930-х - 1950-х років у Центральній та Східній Європі» в Сучасні дискусї про Другу світову війну: збірник наукових статей та виступів українських і зарубіжних дослідників (Львів: ЗУКЦ, 2012), 34-49.

35. Тавокин Е. П., Табатадзе И. А. К К вопросу об исторической памяти о Великой Отечественной войне. Соц̧ис. 2010. № 5. С. 62 .

36. Тощенко Ж. Историческое сознание и историческая память. Анализ современного состояния. URL: http://vivovoco.rsl.ru/ VV/JOURNAL/newhist/himem.htm

37. Тронько П. Інститут національної пам’яті як засіб зцілення від пострадянської ментальності. Дзеркало тижня. 2005. 19-25 листопада (№ 45).

38. Урбан М. Місця пам'яті як фактор міжнаціональних взаємин та конфліктів: казус Польщі та України. Актуальні проблеми вітчизняної та всесвітньої історії: зб. наук. пр. 2015. № 26. С. 180-184. 
39. Хальбвакс М. Коллективная и историческая память. Неприкосновенный запас. 2005. № 2-3. С. 12-35.

40. Чума Б. Іспанська «війна за історію»: політика, історіографія та шкільна освіта. Украӥна модерна. 2012. Ч. 19: Як (не) писати підручники з історії. С. 63-88.

41. Шаповал Ю. Політика національного примирення в Іспанії: що корисне для України. Національна та історична пам'ять: зб. наук. пр. Вип. 5. Київ: ДП НВЦ «Пріоритети», 2012. C. $190-195$.

42. Шаповал Ю. Примирення по-іспанськи. Коспроміс після громадянської війни. День. 2013. 18 лютого.

43. Яковенко Н. Вступ до історії. Київ: Критика, 2007.

44. Яковенко Н., Грицак Я., Зісельс Й. Чесна історія не дуже популярна. URL: https://zbruc.eu/node/84957

45. Ярулин И. Ф. Историческая память как социальный гипноз: к методологии исследования. Вестник Тихоокеанского государственного университета. 2016. № 3 (42).

\title{
Information about the authors: Kalishchuk O. M., Doctor of Science,
} Professor at the Department History of Ukraine and Archaeology, Lesya Ukrainka Eastern European National University 13, Voli Avenue, Lutsk, 43025, Ukraine

\author{
Jarosh J. B., \\ Doctor of Science, \\ Lesya Ukrainka Eastern European National University \\ 13, Voli Avenue, Lutsk, 43025, Ukraine
}

